\title{
Wybrane problemy i dylematy społeczno- -ekonomicznego wartościowania relacji człowiek - środowisko naturalne
}

Współcześnie, wiodącą zasadą polityki ekologicznej, zarówno w wymiarze krajowym, jak i też międzynarodowym, jest zasada zrównoważonego rozwoju. Podstawowym założeniem zrównoważonego rozwoju jest taka realizacja polityki i działań w poszczególnych sektorach gospodarki i życia społecznego, która prowadzi do zachowania zasobów i walorów środowiska naturalnego w stanie zapewniającym trwałe, nie doznające uszczerbku, możliwości korzystania z nich, zarówno przez obecne jak i przyszłe pokolenia, przy jednoczesnym zachowaniu trwałości funkcjonowania procesów przyrodniczych ${ }^{1}$ oraz naturalnej różnorodności biologicznej² ${ }^{2}$. Istotą zrównoważonego rozwoju jest równorzędne traktowanie racji społecznych, ekonomicznych i ekologicznych, co oznacza konieczność integrowania zagadnień ochrony środowiska z politykami w poszczególnych dziedzinach gospodarki ${ }^{3}$.

Człowiek zyjący w XXI wieku staje bardzo często przed koniecznością dokonywania wyborów pomiędzy wartościami lub dobrami, kierując się rozumem, wiarą, doświadczeniem, opierając się o różnorodne systemy światopoglądowe. Powinien jednak zadawać sobie pytanie o hierarchię wartości i dóbr oraz o wzajemne relacje pomiędzy nimi. Co jest ważniejsze: dobrobyt czy pokój, ochrona zdrowia czy edukacja, rozwój gospodarczy czy ochrona środowiska? Czy istnieją wartości absolutne, a jeżeli tak, to jakie: życie pojedynczego człowieka, czy rozwój całej społeczności?

Człowiek współczesny, zarówno w wymiarze indywidualnym, jak i też w wymiarze społecznym, jest uwikłany $\mathrm{w}$ różne dylematy i niestety na podstawie własnego

Zob. szerzej A. Przyborowska-KLimczak, Ochrona przyrody. Studium prawnomiędzynarodowe, Lublin 2004, s. 25 i n.

2 Por. P. LeroY, Political modernisation and the renewal of environmental policy arrangements, [w:] Sustainable development an european view, M.R.Dudzińska, A.Pawłowski, Lublin 2000, s. 9 i n.

3 Zob. D. Maśniak, Ubezpieczenia ekologiczne, Kraków 2003, s. 21 i n. 
wyboru pozbawiony jest komfortu opierania się o jeden system prawd i wartości uniwersalnych. Często skutkuje to m.in. trudnością w wypracowaniu w wielu sferach aktywności ludzkiej katalogu jednoznacznych i akceptowanych przez ogół reguł postępowania, wolnych od relatywizmu. Człowiek współczesny chętnie ucieka w świat nieprecyzyjnych pojęć i niejasnych sformułowań, dystansując się jednocześnie od brania odpowiedzialności za sprawy rudymentarne. Te zjawiska i procesy występują w sposób niezwykle wyraźny w relacjach człowiek - środowisko naturalne.

Na przestrzeni dziejów w różnorodny sposób kształtował się charakter tych relacji, począwszy od lęku człowieka pierwotnego przed żywiołami przyrodniczymi, poprzez fascynację pięknem środowiska naturalnego, do rabunkowej gospodarki zasobami naturalnymi i degradacji środowiska, ku zadumie nad potrzebą zrównoważonego rozwoju ${ }^{4}$. „Wspomniany człowiek poprawia również naturę, ingeruje $w$ jej prawa i tajemnice, niszczy to co naturalne w środowisku naturalnym, ingeruje $\mathrm{w}$ przyrodę, często ją niszczy za cenę mylnie rozumianego rozwoju ludzkości’s. Sfera ta jest szczególnie dotknięta piętnem konieczności dokonywania nie rzadko trudnych wyborów pomiędzy dobrami ekonomicznymi, gospodarczymi, a ekologicznymi. Jest naznaczona potrzebą udzielania odpowiedzi na pytanie, jak dalece wartość życia i jakość zdrowia ludzkiego są wyznacznikami priorytetów programowania polityki zrównoważonego rozwoju oraz w jaki sposób wpływają na model zarządzania wykorzystaniem zasobów naturalnych i na system ochrony środowiska naturalnego.

W jakim kontekście można rozważać ekonomiczną wartość środowiska naturalnego i w jaki sposób ekonomiczna kategoryzacja środowiska naturalnego może odnosić się do pojmowania tego środowiska jako dobra wyższego rzędu, mającego bezpośredni wpływ na jakość życia ludzkiego, a zatem dobra wymykającego się niejako spod ocen li tylko ekonomicznych? ${ }^{6}$ Pojmowanie relacji człowiek - środowisko jest bardzo zróżnicowane w poszczególnych nurtach myśli filozoficznej i poglądów moralnych, w religiach i w prawno-ustrojowych koncepcjach organizacji państwa. Problematyka ta eksplorowana jest również na wielu polach naukowych w ramach różnorodnych dyscyplin nauk ekologicznych, takich jak: ekologia, sozologia, sozotechnika, sozoekonomia, etyka środowiskowa, bioetyka, ekofilozofia, ekoteologia, polityka ekologiczna ${ }^{7}$, jak i też w naukach prawnych, w szczególności w ramach prawa ochrony środowiska.

4 Rozważając tego typu problemy warto sięgnąć do opracowania A. Kalınowskiej, Ekologia wybór na nowe stulecie, Warszawa 2002.

5 S. KaSPRZAK, Normatywny wymiar ekologicznych i sozologicznych idei w systemie prawa państwowego i kościelnego, Lublin 2003, s. 34.

6 Zob. np. G.Anderson, J.Śleszyński (red.), Ekonomiczna wycena środowiska przyrodniczego, [w:] Wartościowanie dóbr i zasobów środowiska, Białystok 1996.

7 Zob. szerzej na temat nauk ekologicznych: J.M. DoŁĘGA, Z filozofii nauk ekologicznych, [w:] Ochrona środowiska społeczno-przyrodniczego w filozofii i teologii, (red.) J.M.Dołęga, 
Na współczesne problemy środowiska naturalnego należy spojrzeć szeroko, poprzez pryzmat wielu zjawisk, procesów i zagadnień, zarówno ekonomicznych, finansowych, prawnych, administracyjnych, ustrojowych, technologicznych, jak i też filozoficznych i moralnych. W takim szerokim kontekście należy umiejscowić zagadnienia dotyczące pojmowania idei zrównoważonego rozwoju.

Punktem wyjścia do rozważań są kwestie z pogranicza filozofii, moralności, ekonomii, finansów i prawa, dotyczące racjonalnego gospodarowania zasobami naturalnymi, poprawy stanu środowiska naturalnego i jego ochrony oraz regulacji i kształtowania postaw i zachowań ludzi oraz podmiotów w odniesieniu do środowiska naturalnego, a także wyznaczania granic prawnych tych zachowań i sankcjonowania ich przekroczenia. Przede wszystkim należy zastanowić się nad istotą stosunku człowieka do środowiska naturalnego na początku XXI wieku. Jak zauważa Z.Hull „szeroko rozumiana i coraz częściej podnoszona problematyka ekofilozoficzna nabiera dzisiaj szczególnego znaczenia właśnie z racji społeczno-praktycznych: rozpoznanie aktualnego i określenie pożądanego stosunku człowieka (społeczeństwa) do środowiska przyrodniczego jest nie tylko poznawczo ale i egzystencjalnie ważne"8.

Człowiek wywiera ogromny wpływ na życie biologiczne na Ziemi i na jego otoczenie. Jest w stanie wywierać zarówno wpływ pozytywny, jak i też negatywny, przyczyniający się do degradacji otoczenia, w którym żyje. Możliwość wywierania tak znaczącego wpływu na całą planetę powoduje, że interakcyjna aktywność człowieka powinna być rozważnie programowana. „Człowiek jest pierwszym gatunkiem biologicznym na Ziemi, który zdolny jest zmodyfikować powierzchnię całej planety, jej biosferę, atmosferę i klimat w sposób bardzo głęboki i globalny" . Zrozumienie tej prawdy musi znaleźć się u podstaw rozważań będących przedmiotem niniejszej pracy. Jeżeli zgadzamy się, że najsilniejszym instynktem człowieka jest instynkt życia i wola przeżycia i jednocześnie przyjmujemy założenie, że człowiek powinien mieć świadomość skali i siły swojego oddziaływania na otaczający go świat i zarazem rozumieć, że egzystencja ludzka jest związana ze stanem środowiska naturalnego, to powinniśmy uznać racjonalność postępowania i pozytywną reakcję człowieka w odniesieniu do środowiska naturalnego za zachowanie pożądane.

J.Czartoszewski, A.Skowroński, Warszawa 2001, s. 25 i n. oraz S.Wrzosek, Zarzadzanie środowiskiem przez administracje publiczna w Polsce, Białystok 1999, s. 18 in.

8 Z. Hull, O dwóch sposobach pojmowania i uprawiania filozofii ekologii, [w:] Ochrona środowiska spoleczno-przyrodniczego..., (red.) J.M. Dolęga...,op. cit. s. 38.

9 E. Kośmicki, Problem odpowiedzialności czlowieka za ewolucję, [w:] Ochrona środowiska społeczno-przyrodniczego..., (red.) J.M. Dołęga...,op. cit. s. 55. 
Obok racjonalności, drugim kryterium zachowania człowieka powinna być, przy zachowaniu wolności wyboru, odpowiedzialność za własne życie, a także za życie społeczności globalnej, i to nie tylko odpowiedzialność za ochronę i utrzymanie życia, ale również w rozumieniu współczesnym - za jego odpowiednią jakość i właściwy standard. Odpowiedzialność nie jest niestety "popularną" cechą postępowania współczesnego człowieka. „Człowiek nie jest zadowolony z tego, że ciąży na nim tak duża odpowiedzialność, odpowiedzialność za losy całej ludzkości.[...] Proces cedowania odpowiedzialności na kogoś innego jest dość powszechnym zjawiskiem w kulturze zachodniej”'10. A zatem, jeżeli człowiek ma szacunek do własnego życia i życia innych, to również ma podstawę do racjonalnego i odpowiedzialnego stosunku do środowiska naturalnego. Szacunek do życia jako podstawowej i najważniejszej wartości kształtuje szacunek do innych wartości i dóbr, w tym do otaczającej nas natury. Dlatego też w państwach o systemach autorytarnych i totalitarnych, zorganizowanych w sposób niedemokratyczny, których władza nie ma szacunku dla życia ludzkiego, przeważnie nie ma również warunków do dbałości o stan środowiska naturalnego. Chociaż oczywiście nie jest to żelazną regułą, gdyż niestety również w państwach demokratycznych obserwujemy często zjawisko instrumentalnego podejścia do korzystania z zasobów naturalnych i do ochrony środowiska, jednakże przeważnie powodowane to jest dokonywaniem świadomego wyboru określonych priorytetów polityki rozwoju społeczno-gospodarczego, a nie brakiem poszanowania dla życia ludzkiego.

Warunkami przetrwania gatunku ludzkiego jest m.in. przetrwanie przyrody i zachowanie bioróżnorodności. J.Życiński podkreśla, że „przyroda, która dla wielu generacji stanowiła dziedzinę dramatycznej walki o byt, ujawnia nam dziś ostrzej niż kiedykolwiek swe piękno [...] Tam, gdzie wcześniejsze generacje dostrzegały jedynie chaos nieskoordynowanych procesów, dla nas ujawnia się fascynująca rzeczywistość ukrytej głębi racjonalnych struktur"11. Jeżeli przyjmiemy racjonalność i odpowiedzialność za podstawę kształtowania się pozytywnych postaw człowieka względem otaczających go składników i elementów przyrody i zasobów naturalnych, to powinniśmy zastanowić się także nad innymi uwarunkowaniami tych postaw, tzn. w szczególności nad uwarunkowaniami społeczny$\mathrm{mi}$, technologicznymi, gospodarczymi, finansowymi i prawnymi.

W sensie społecznym, środowisko naturalne rozumiane jako dobro, nie powinno być postrzegane jako własność jednostek, ale powinno być traktowane jako dobro wspólne stanowiące „funkcję tych wszystkich warunków, które zapewniają ludziom w społeczeństwie życie godne człowieka" ${ }^{12}$. Chęć przebywania w czystym

\footnotetext{
10 A. KuzIor, Wolność wyboru a problem odpowiedzialności - rozważania Ericha Fromma, [w:] Ochrona środowiska społeczno-przyrodniczego..., (red.) J.M.Dołęga..,s. 294 i n.

11 J. Życiśski, Ulaskawienie natury, Kraków 1992, s. 180.

12 Zob.: S. KasprZak, Normatywny..., op.cit. s. 57.
} 
środowisku, oddychania nie skażonym powietrzem, picia czystej wody, jest wyrazem postrzegania elementów biosfery jako dobra wspólnego. Jednostki przenoszą jednocześnie te pragnienia na poziom społeczności przy konstatacji braku osobistych, indywidualnych możliwości wywierania wpływu na osiągnięcie pożądanego stanu środowiska naturalnego. Społeczeństwo ma zatem naturalne prawo domagania się od jednostek zachowań realizujących ideał zachowania dobra wspólnego, jak i też samo jest adresatem postulatów jednostek.

Należy wrócić do zasygnalizowanego wcześniej pojęcia jakości życia ludzkiego jako przedmiotu kryterium relacji człowieka do środowiska naturalnego. Bardzo często jako uzasadnienie podejmowania przez władze publiczne określonych działań w zakresie ochrony środowiska, w tym w szczególności realizowania inwestycji, w wyniku których powstaje lub zostaje zmodernizowana infrastruktura techniczna służąca np. uzdatnianiu i dostarczaniu wody pitnej, czy też utylizacji odpadów, podawany jest argument konieczności poprawy jakości życia ${ }^{13}$. Bardzo wyraźnie aspekt ten jest eksponowany w założeniach programowych polskiej polityki ekologicznej, która podkreśla, że nadrzędną wartością w polityce ekologicznej państwa jest człowiek. Oznacza to, że zdrowie społeczeństwa jako całości, komfort środowiska, w którym żyją i pracują społeczności lokalne oraz życie i zdrowie każdego obywatela są głównym, niepodważalnym kryterium w realizacji polityki ekologicznej na każdym szczeblu: w miejscu pracy i zamieszkania, na szczeblu lokalnym, regionalnym i krajowym. Obywatel ma zatem prawo domagać się, ażeby władza publiczna w swoich działaniach na rzecz bezpieczeństwa ekologicznego realizowała ideały tzw. dobrej administracji ${ }^{14}$. W tym kontekście trzeba zatem zastanowić się, co wyznacza obecnie poziom i standardy jakości życia? Czy zaspokajanie potrzeb ekologicznych ${ }^{15}$ (rozumianych zbiorczo jako chęć życia w nieskażonym środowisku naturalnym i korzystania z zasobów naturalnych) jest naturalnym, pożądanym elementem właściwej jakości życia?

Współczesne pojmowanie jakości życia jest uwarunkowane zdywersyfikowanym poziomem życia poszczególnych społeczeństw Intuicyjnie można przyporządkować pojęcie „jakości życia” społeczeństwom rozwiniętym i zamożnym, gdyż zawiera ono w swej treści nie tylko poczucie materialnych podstaw egzystencji, ale także potrzebę zaspokajania egzystencjalnych potrzeb wyższego rzędu, np. dobrze zorganizowanej opieki zdrowotnej lub systemu edukacyjnego, czy

13 Zobacz na ten temat M. RudNICKI, Odpowiedzialność wiadz publicznych za realizację zadań w dziedzinie ochrony środowiska, [w:] Prawość $i$ Godność, Księa pamiątkowa w 70 rocznicę urodzin Profesora Wojciecha Laczkowskiego, Lublin 2003, s. 207 i n.

14 Zob. na ten temat Z. NiEwIADomski, Prawo do dobrej administracji - aspekty procesowe, ustrojowe i materialne, Biuletyn Biura Informacji Rady Europy, Nr 4/2003, s. 42 oraz A.Zoll, Dobra administracja jako prawo obywatela, Biuletyn Biura Informacji Rady Europy, Nr 4/2003, s. 9.

15 Por. S. Kasprzak, Normatywny..., s. 57. 
też życia w czystym środowisku naturalnym. Pojęcie „jakości życia” w społeczeństwach biednych, rozwijających się, nie zawiera w swej istocie dążenia do zaspokajania egzystencjalnych potrzeb wyższego rzędu, ale jest tożsame z pojęciem "przeżycia” lub "godnego życia”. Dlatego też omawiane pojęcie nie jest łatwe do jednoznacznego zdefiniowania. Bardzo trudno jest nie przyznać racji tym, którzy z pesymizmem i niewiarą w solidaryzm społeczności globalnej twierdzą, ze potrzeby ekologiczne rozbudzone są w społeczeństwach bogatych i rozwiniętych i tam właśnie stanowią istotny element pożądanej jakości życia. Ponadto należy dostrzec różnicę w postrzeganiu potrzeb ekologicznych w społeczeństwie bogatym, świadomym stopnia degradacji środowiska naturalnego i mającym wysoko rozwiniętą ogólną świadomość ekologiczną, a postrzeganiem tych potrzeb w społeczeństwie biednym, nie świadomym zagrożeń ekologicznych i degradacji otaczającego je środowiska. W związku z tym należy zwrócić uwagę na problem sprawiedliwego udziału społeczeństw w przestrzeni ekologicznej ${ }^{16}$.

Stan środowiska naturalnego bardzo mocno oddziałuje na zaspokajanie egzystencjalnych potrzeb człowieka i jest związany z potrzebami ekologicznymi, które można scharakteryzować jako wymagania odnoszące się do biologicznych, fizycznych, chemicznych i technologicznych właściwości poszczególnych elementów środowiska naturalnego. Człowiek dążąc do uzyskania zadawalającego go poziomu życia i odpowiedniej jego jakości dokonuje wyboru pomiędzy różnymi dobrami. Niestety, dobra ekologiczne bardzo często są traktowane jako dobra, które zajmują ostatnie miejsce w hierarchii i muszą ustępować np. dobrobytowi materialnemu, czy też bezpieczeństwu socjalnemu. Traktowanie dóbr ekologicznych jako dóbr ostatniej kategorii zaspokajania, często w sposób niezauważalny w krótkim okresie, prowadzi do trwalych i negatywnych zmian w bezpośrednim środowisku życia człowieka oraz wpływa ujemnie na jego stan zdrowia. Trafnie zauważa S. Kasprzak, że „deprawacja potrzeb ekologicznych, czyli swoistego rodzaju zwyrodnienie oczekiwań i zamiarów człowieka, prowadzi bardzo często do czasowej lub trwałej utraty zdrowia, a nawet życia"17.

Dlatego też niezwykle istotnym warunkiem wyboru i realizacji potrzeb ekologicznych jako potrzeb należących do pierwszorzędnych potrzeb egzystencjalnych mających istotny wpływ na jakość życia jest świadomość ekologiczna. Celem rozwoju świadomości ekologicznej człowieka jest wykształcenie takich zachowań, które byłyby nastawione na ochronę środowiska zarówno w wymiarze jednostkowym, jak i też w wymiarze ogólnym, dotyczącym całego społeczeństwa, jak i też poszczególnych jego grup, np. konsumentów lub przedsiębiorców. Kształtowanie

16 Zob. szerzej M. Carley, P. Spapens, Dzielenie się światem. Zrównoważonysposób życia i globalnie sprawiedliwy dostęp do zasobów naturalnych wXXI wieku, Białystok - Warszawa 2000, s. $85 \mathrm{in}$.

17 Ibidem, op. cit. s 55 . 
się świadomości ekologicznej i zachowań proekologicznych w poszczególnych społeczeństwach zależne jest od ogólnego rozwoju kulturalnego i społecznego i gospodarczego ${ }^{18}$. We współczesnych, wysoko rozwiniętych społeczeństwach istnieją znaczne niewykorzystane potencjały, które poprzez prawidłowo realizowaną edukację ekologiczną i politykę informacyjną przyczynić się mogą do rozwoju właściwych, proekologicznych wzorców zachowań społecznych, konsumenckich, działań gospodarczych i dobrych praktyk produkcyjnych. Wysoko rozwinięta świadomość ekologiczna oraz pozytywne i przyjazne dla środowiska naturalnego postawy, zachowania i działania, będące istotnymi podstawami zrównoważonego rozwoju, wymagają dobrze zaplanowanego i konsekwentnie realizowanego kształcenia obejmującego różnorodne dziedziny ochrony środowiska. Organizatorami systemu kształcenia muszą być zarówno instytucje publiczne i prywatne, jak i też organizacje pozarządowe ${ }^{19}$. Kształcenie musi być uzupełniane o dobrze zorganizowaną politykę informacji o środowisku naturalnym i o jego stanie. Tylko takie kompleksowe działania mogą służyć rozwojowi i upowszechnianiu trwałych, proekologicznych wzorców zachowań i postaw polityków, przedsiębiorców, konsumentów i ogółu społeczeństwa. Kształcenie, informowanie i wiedza na temat środowiska naturalnego znajdują swoje oparcie w konwencji z Aarhus ${ }^{20}$, dotyczącej dostępu do informacji, udziału społeczeństwa i opinii publicznej w procesach decyzyjnych i dostępie do wymiaru sprawiedliwości w dziedzinie środowiska.

Każda działalność człowieka w środowisku naturalnym pociąga za sobą określone jego przemiany, których charakter uzależniony jest od rodzaju ludzkiej aktywności, jej intensywności i zgodności z obowiązującymi normami. Problem ingerencji człowieka $\mathrm{w}$ środowisko naturalne związany jest z zasadniczym sporem dotyczącym określenia priorytetów rozwoju cywilizacyjnego, w szczególności $\mathrm{w}$ dobie, kiedy postęp realizowany rzekomo $\mathrm{w}$ imię dobra człowieka, zaczął bezpośrednio zagrażać jego zdrowiu i życiu ${ }^{21}$. Jednym z ważniejszych problemów

18 Zob. L. Möller, Proekologiczna edukacja oraz informacja o środowisku jako główne składniki świadomości ekologicznej, [w:] Międzynarodowe zarządzanie środowiskiem. Tom I, Interdyscyplinarne założenia proekologicznego zarządzania przedsiębiorstwem. Studia Ekonomiczne, M. Kramer, M. Urbaniec, A. Kryński (red.), (rec. nauk. - K. Biernat, M. Rudnicki), Warszawa 2004, s. 133 i n.

19 Zob. uwagi krytyczne dotyczące ksztalcenia w dziedzinie ochrony środowiska R. Paczuski, O niedostatku nauczania prawa ochrony środowiska w Polsce, [w:] Zasada zrównoważonego rozwoju w prawie i praktyce ochrony środowiska, K. Równy, J. Jabłoński (red.), Warszawa 2002, s. 293 i n.

20 Zob. Konwencja o dostępie do informacji, udziale społeczeństwa w podejmowaniu decyzji oraz dostępie do sprawiedliwości w sprawach dotyczących środowiska, sporządzona dnia $25 \mathrm{czerw}$ ca 1998 roku w Aarhus w Danii, ratyfikowana przez Polskę w dniu 21 czerwca 2001 r. (ustawa z dnia 21 czerwca 2001 r. o ratyfikacji Konwencji o dostępie do informacji, udziale spoleczeństwa w podejmowaniu decyzji oraz dostępie do sprawiedliwości w sprawach dotyczących środowiska (Dz. U. z 2001 r. Nr 89, poz. 970).

21 Zob. Z. Karaczun, L. LudekA, Ochrona środowiska, Warszawa 1996, s. 263. 
środowiskowych i cywilizacyjnych jest to, że współcześnie rozwój gospodarczy i postęp naukowo-techniczny są ściśle od siebie zależne i wzajemnie na siebie oddziałują. Realizując program rozwoju gospodarczego przy użyciu dostępnej techniki i technologii dochodzi często do nadmiernej eksploatacji środowiska naturalnego ${ }^{22}$. W wyniku tej eksploatacji człowiek otrzymuje podstawowe surowce produkcyjne i równocześnie przyczynia się do powstania szeregu zanieczyszczeń środowiska. Struktura tych zanieczyszczeń powstających w wyniku działalności eksploatacyjnej i produkcyjnej jest wynikiem zarówno działalności gospodarczej jak i poziomu technologicznego w poszczególnych dziedzinach działalności ${ }^{23}$.

Oprócz aspektów gospodarczych, na kształt środowiska naturalnego wpływ mają także sprawy społeczne. Szczególne zwrócenie uwagi na aspekt relacji społecznych w odniesieniu do środowiska naturalnego jest uzasadnione tym, że trwałe przekształcenia w środowisku naturalnym powodują także zmianę stosunku społeczeństwa do natury. Wynika z tego, zdaniem K.Górki wniosek, że współdziałanie społeczeństwa i natury musi być badane nie tylko w układzie statycznym, lecz także dynamicznym, umożliwiającym poznanie zarówno samej istoty tego działania jak i kierunku jego ewolucji ${ }^{24}$.

Czy rozwój ten ma być podporządkowany gospodarce, czy też osią tego rozwoju ma być ochrona i zachowanie zasobów środowiska naturalnego? Czy może najrozsądniejsze jest zrównoważenie celów gospodarczych, społecznych i ekologicznych? ${ }^{25}$ Tak stawiany problem świadczy o jego znaczeniu w życiu globalnej społeczności i od lat skłania do przemyśleń i refleksji2 ${ }^{26}$.

Jak podkreśla W.Michajłow, kluczową sprawą jest dokładne określenie przyczyn i skutków, a także dalszych następstw przemian zachodzących w środowisku w wyniku działalności społecznej i gospodarczej człowieka. Dokonane oceny powinny służyć do określenia skutecznych sposobów zapobiegania, bądź ograniczenia ujemnych następstw dla środowiska, a przede wszystkim dla człowieka ${ }^{27}$.

${ }_{22}$ Zob. szerzej na temat racjonalności zużycia zasobów naturalnych i koncepcji tzw. „mnożnika cztery" jako relacji pomiędzy zwiększaniem dobrobytu a ograniczaniem zużycia zasobów środowiska naturalnego: E.U.von Weizsacker, A.B.Lovins, L.Hunter Lovins, Mnożnik cztery, podwojony dobrobyt - dwukrotnie mniejsze zużycie zasobów naturalnych, Torun 1999.

23 Zob. A. Ciborowski, Polityka ksztaltowania środowiska, Warszawa 1981, s. 80 - 82 oraz G. Dobrzański, B. Dobrzańska, D. KięCZEwski, E. ŁaPIŃsKa,, Ochrona środowiska przyrodniczego, Białystok 1998, s. 131 - 132.

24 Zob. K. Górka, B. Poskrobko, W. Radecki, Ochrona środowiska. Problemy spoleczne, ekonomiczne i prawne, Warszawa 1998, s. 16-20.

25 Zob.np. T. Ży LICZ, Ekonomia wobec problemów środowiska przyrodniczego, Warszawa 1990.

26 Zob.np. S. CZAJA, B. Fiedor, Z. JAKUBCZYK, Ekologiczne uwarunkowania wzrostu gospodarczego w ujęciu wspótczesnej teorii ekonomii, Białystok - Kraków 1992.

27 Zob. E. Ha£oń, W. MichajŁow, Człowiek i środowisko, Wrocław 1979, s. 113-114. 
Jak trudno jest rozwiązywać te dylematy w skali globalnej świadczy chociażby to, że międzynarodowe porozumienia służące ochronie środowiska są podpisywane jedynie $\mathrm{w}$ tych dziedzinach, które są w pełni zgodne $\mathrm{z}$ narodowymi interesami poszczególnych państw $w^{28}$.

Dlatego w poszukiwaniu kompromisu pomiędzy gospodarką a środowiskiem naturalnym należy opierać się na wielowątkowej analizie problemu, uwzględniającej zarówno podstawowe prawa przyrodnicze, jak i też społeczne i ekonomiczne ${ }^{29}$.

W Drugiej Polityce Ekologicznej Państwa ${ }^{30}$ podkreśla się, że człowiek wraz ze swoją działalnością jest ściśle sprzężony z systemem przyrodniczym. Zachowanie równowagi w tym systemie wymaga spójnego i łącznego zarządzania zarówno dostępem do zasobów środowiska oraz likwidacją i zapobieganiem powstawaniu negatywnych dla środowiska skutków działalności gospodarczej (ochrona środowiska), jak i racjonalnym użytkowaniem zasobów przyrodniczych (gospodarka wodna, leśnictwo, ochrona i wykorzystanie zasobów surowcowych i glebowych, planowanie przestrzenne). Powinno to znaleźć odbicie w odpowiednich strukturach zarządzania na szczeblu krajowym, regionalnym i lokalnym oraz takim podziale kompetencji, zadań i dostępnych procedur, aby cele polityki ekologicznej na każdym szczeblu były wyznaczane w oparciu o prawidłowe rozpoznanie potrzeb, zaś środki do ich osiągnięcia były dobierane przede wszystkim w oparciu o kryteria efektywności ekologicznej i ekonomicznej. Tylko w takim przypadku można mówić o zapewnieniu obywatelom bezpieczeństwa ekologicznego ${ }^{31}$. Bezpieczeństwo ekologiczne może być pojmowane zarówno jako cel

28 Zob. A. BuDNIKowski, Ochrona środowiska jako problem globalny, Warszawa 1998, s. 156-159.

29 Zob. J. Machowski, Ochrona środowiska. Prawo i zrównowaźny rozwój, Warszawa 2003, s. 65-66.

30 W literaturze przedmiotu zwraca się uwagę na fakt, że II PEP została przyjęta przez Radę Ministrów dnia 13 czerwca 2000 r., a następnie dnia 22 sierpnia 2001 r. uchwalona przez Sejm. Artykuł 10 ust. 2 ustawy z dnia 27 lipca 2001 r. o wprowadzeniu ustawy Prawo ochrony środowiska, ustawy o odpadach oraz o zmianie niektórych ustaw (Dz.U. z 2001 r. Nr 100, poz. 1085), nakazywał opracowanie nowej polityki ekologicznej, wyznaczając na to termin do 31 grudnia 2002 roku. Tymczasem II PEP uchwalona została jeszcze przed wejściem w życie ustawy z dnia 27 kwietnia 2001 roku Prawo ochrony środowiska (Dz.U.z 2001 r., Nr 62, poz.627 z późn.zm.). Zastanowienia wymaga więc, jak zauważa M.Bar, czy II PEP była w pełni zgodna z wymogami wspomnianej ustawy. M.Bar zwraca uwagę na fakt, że II PEP obejmuje lata 2000 - 2025, gdy tymczasem zgodnie $z$ art. 14 ust. 2 ustawy Prawo ochrony środowiska politykę ekologiczną przyjmuje się na 4 lata, z tym, że przewidziane w niej działania w perspektywie obejmują kolejne 4 lata; zob. M.Bar, J.Boć, M.Bojarski, M.Górski, J.Jendrośka (red.) J.Jerzmański, E.KaletaJagiełło, A.Lipiński, K.Nowicki, J.Rotko, W.Skarżyńska, T.Tatomir, Ustawa Prawo ochrony środowiska. Komentarz, Wrocław, 2001 r. Na temat charakteru prawnego polityki ekologicznej zobacz także: E.Radziszewski, Prawo ochrony środowiska. Przepisy i komentarz, Warszawa 2003.

31 Zob. Uchwała Sejmu RP z dnia 22 sierpnia 2001 roku w sprawie nowej polityki ekologicznej państwa. Co ciekawe uchwała ta nie została opublikowana w Monitorze Polskim. Eksperci BSiE Kancelarii Sejmu RP twierdzą, że uchwała ta jedynie aprobująco odnosila się do przyjętego wcześniej przez Radę Ministrów dokumentu dotyczącego nowej polityki ekologicznej. 
funkcjonalny polityki ekologicznej oraz jako norma prawna, występująca zarówno w prawie wewnętrznym, jak i też międzynarodowym, nakładająca na władze publiczne obowiązek zapewnienia bezpieczeństwa ekologicznego współczesnym i przyszłym pokoleniom w zgodzie z zasadą zrównoważonego rozwoju.

Autor starał się jedynie zasygnalizować wybrane wątki rozważań o zrównoważonym rozwoju - idei słusznej co do istoty, ale wydaje się, że uwikłanej współcześnie w szereg dylematów, często o bardzo głębokiej wymowie społecznej, gospodarczej i środowiskowej.

\section{Literatura}

Anderson G., Śleszý́ski J. (red.), Ekonomiczna wycena śodowiska przyrodniczego, [w:] Wartościowanie dóbr i zasobów środowiska, Białystok 1996,

Bar M., Boć J., Bojarski M., Górski M., Jendrośka J. (red.) Jerzmański J., Kaleta-Jagiełło E., Lipiński A., Nowicki K., Rotko J., Skarżyńska W. Tatomir T., Ustawa Prawo ochrony środowiska. Komentarz, Wrocław 2001,

BudNikowski A., Ochrona środowiska jako problem globalny, Warszawa 1998,

CARLEy M., SPapens P., Dzielenie się światem. Zrównoważony sposób życia i globalnie sprawiedliwy dostep do zasobów naturalnych w XXI wieku, Białystok - Warszawa 2000,

Ciborowski A., Polityka kształtowania środowiska, Warszawa 1981,

Czaja S., Fiedor B., JakubczyK Z., Ekologiczne uwarunkowania wzrostu gospodarczego w ujęciu wspólczesnej teorii ekonomii, Białystok - Kraków 1992,

Dobrzański G., Dobrzańska B., Kielczewski D., Łapińska E., Ochrona środowiska przyrodniczego, Białystok 1998,

DoєĘGA J.M., Z filozofii nauk ekologicznych, [w:] Ochrona środowiska spoleczno-przyrodniczego w filozofi i teologii, (red.) J.M.Dołęga, J.Czartoszewski, A.Skowroński, Warszawa 2001,

Górka K., Poskrobko B., Radecki W., Ochrona środowiska. Problemy społeczne, ekonomiczne i prawne, Warszawa 1998 ,

HaŁoń E., MichajŁow W., Człowiek iśrodowisko, Wrocław 1979,

Hull Z., O dwóch sposobach pojmowania i uprawiania filozofii ekologii, [w:] Ochrona środowiska spoleczno-przyrodniczego..., (red.) J.M.Dołęga...,.

KalinowsKa A., Ekologia - wybór na nowe stulecie, Warszawa 2002,

Karaczun Z. , Ludeka L., Ochrona środowiska, Warszawa 1996,

KasprzaK S., Normatywny wymiar ekologicznych i sozologicznych idei $w$ systemie prawa państwowego i kościelnego, Lublin 2003,

Kośmicki E., Problem odpowiedzialności czlowieka za ewolucję, [w:] Ochrona środowiska spoleczno-przyrodniczego..., (red.) J.M.Dołęga.....

KuzioR A., Wolność wyboru a problem odpowiedzialności - rozważania Ericha Fromma, [w:] Ochrona środowiska społeczno-przyrodniczego..., (red.) J.M.Dolęga...,

LEROY P., Political modernisation and the renewal of environmental policy arrangements, [w:] Sustainable development an european view, M.R.Dudzińska, A.Pawłowski, Lublin 2000,

Machowski J., Ochrona środowiska. Prawo i zrównoważony rozwój, Warszawa 2003,

MaśniaK D., Ubezpieczenia ekologiczne, Kraków 2003, 
Möller L., Znaczenie polityki ochrony środowiska z punktu widzenia przedsiębiorstw w aspekcie międzynarodowym, [w:] Międzynarodowe zarzadzanie środowiskiem. Tom I, Interdyscyplinarne założenia proekologicznego zarzadzania przedsiębiorstwem. Studia Ekonomiczne, M.Kramer, M.Urbaniec, A.Kryński (red.), (rec. nauk. - K.Biernat, M.Rudnicki), Warszawa 2004,

Möller L., Proekologiczna edukacja oraz informacja o środowisku jako główne składniki świadomości ekologicznej, [w:] Międzynarodowe zarządzanie środowiskiem..., M.Kramer...,

Niewiadomski Z., Prawo do dobrej administracji - aspekty procesowe, ustrojowe i materialne, Biuletyn Biura Informacji Rady Europy, Nr 4/2003,

Paczuski R., O niedostatku nauczania prawa ochrony środowiska w Polsce, [w:] Zasada zrównoważonego rozwoju w prawie i praktyce ochrony środowiska, Równy K., Jabłoński J. (red.), Warszawa 2002 ,

Przyborowska-Klimczak A., Ochrona przyrody. Studium prawnomiędzynarodowe, Lublin 2004,

Radziszewski E., Prawo ochrony środowiska. Przepisy i komentarz, Warszawa 2003.

Rudnicki M., Odpowiedzialność wtadz publicznych za realizację zadań w dziedzinie ochrony środowiska, [w:] Prawość i Godność, Księga pamiątkowa w 70 rocznicę urodzin Profesora Wojciecha Łaczkowskiego, Lublin 2003,

Weizsacker von E.U., Lovins A.B., Hunter Lovins L., Mnożnik cztery, podwojony dobrobyt - dwukrotnie mniejsze zuzycie zasobów naturalnych, Toruń 1999,

Wrzosek S., Zarzadzanie środowiskiem przez administrację publiczna w Polsce, Białystok 1999 ,

Zoll A., Dobra administracja jako prawo obywatela, Biuletyn Biura Informacji Rady Europy, $\mathrm{Nr}$ $4 / 2003$,

Życiński J., Ulaskawienie natury, Kraków 1992,

Żylicz T., Ekonomia wobec problemów środowiska przyrodniczego, Warszawa 1990 ,

Agenda 21. Progress Report 1992-1998. Ind Updated Edition, Warsaw 1998.

\title{
Chosen problems and socially-economical dilemmas of the valuation of relation between human and natural environment
}

\author{
SUMMARY
}

In this article autor shows the relation between human and natural environment and the chosen problems connected with this, especially social,technological, economical and law problems and dilemmas connected with ecological safety of the human and the whole biosphere. 